Bangladesh J. Plant Taxon. 27(2): 213-224, 2020 (December)

(C) 2020 Bangladesh Association of Plant Taxonomists

\title{
THE ANATOMICAL STRUCTURES OF THE GENUS IBERIS L. (BRASSICACEAE) IN TURKEY
}

\author{
Burcu Yilmaz ÇitaK* and HÜSEyin Dural \\ Department of Biology, Faculty of Science, University of Selçuk, Konya, Turkey
}

Keywords: Anatomy; Candytufts; Cruciferae; Iberis, Mustard family; UPGMA.

\begin{abstract}
The present study was designed to analyse the anatomy of the vegetative and reproductive parts of Turkish Iberis species from a systematic point of view. Samples of leaves, stems, roots, fruits, and seeds of each species were collected, fixed, and processed according to the paraffin method for light microscopy. The numerical analysis derived from 11 anatomical characteristics showed that the number and dimensions of vessels in the root, presence of aerenchyma in the leaf, number and dimensions of palisade parenchyma, and mesophyll type were useful for grouping the Iberis taxa. The testa was composed of four layers: the epidermis, subepidermis, compact tissue, and parenchyma. The testa thickness was a significant character to distinguish the investigated Iberis species. In this study, the traditional classification of Turkish Iberis species was mostly congruent with the dendrogram generated vegetative anatomical properties.
\end{abstract}

\section{Introduction}

The family Brassicaceae, also named as Cruciferae in reference to its four crossed petals, is commonly called the mustard family. This family contains 52 tribes, 341 genera, and 3997 species (Koch et al., 2012; Kiefer et al., 2014; BrassiBase: https://brassibase.cos.uni-heidelberg.de/, accessed 5 February 2018) distributed worldwide, primarily in temperate regions (Al-Shehbaz, 1984; Al-Shehbaz et al., 2006). The family has economic importance (Franzke et al., 2011; AlShehbaz, 2012; Huang et al., 2016), as it includes the well-known model plant species Arabidopsis thaliana (Linn.) Heynhold, many crops (e.g., cabbage, cauliflower, turnip, rapeseed, canola, radish, and wasabi) and ornamentals (e.g., species of Lobularia Desv., Iberis L., Hesperis L., and Matthiola W.T. Aiton). Although the family is easily recognised by its morphological aspects, it is often difficult to assign an individual plant to a given genus, and there is tremendous controversy regarding its generic and tribal delimitations (Al-Shehbaz et al., 2006; Al-Shehbaz, 2012). More specifically, obtaining plants with mature fruit is highly significant for separating genera in the family Brassicaceae. The genus Iberis is a small group in crucifers, with a total of 28 species in the world (Al-Shehbaz, 2012; Çilden and Zare, 2019). The total number of Iberis species in Turkey is nine (Mutlu, 2012; Oskay, 2017; Çıtak, 2019).

Systematic studies based on the anatomy of vegetative and reproductive parts can be useful to discriminate the species of Brassicaceae (Selvi and Paksoy, 2013; Atçeken et al., 2016). Although quite a few palynological (Çıtak, 2019), embryological (Prabhakar and Vijayaraghavan, 1983), and floral (Busch and Zachgo, 2007) studies have been carried out on Iberis, the investigation of its comparative vegetative and reproductive anatomy remains insufficient for the genus. In order to gain knowledge of the anatomical relationship of Turkish Iberis species, the first comprehensive study, which included representatives of eight species, was conducted herein to evaluate their practicality in the taxonomy of the genus.

*Corresponding author, e-mail: burcuyilmaz@selcuk.edu.tr 


\section{Materials and Methods}

Collection and storage of the plant materials

The plant specimens used in this study were collected during 2015 and 2019 from various localities in Turkey. The information about the voucher specimens is given in Table 1. The anatomical samples of the examined species were stored in the Plant Anatomy Laboratory of Biology Department of University of Selçuk, Konya, Turkey.

Table 1. Locations and collector information of the Turkish Iberis taxa.

\begin{tabular}{|c|c|c|}
\hline Taxa & Location & Collector number \\
\hline \multirow[t]{2}{*}{$\begin{array}{l}\text { Iberis sempervirens L. } \\
\text { (I1) }\end{array}$} & $\begin{array}{l}\text { C4 Konya: Beyşehir, Dumanlı Mountain, } 1800 \text { m., } \\
\text { 07.06.2018 }\end{array}$ & B. Çıtak-340 (**) \\
\hline & $\begin{array}{l}\text { C3 Antalya: Akseki, Atlarkırı Mountain, } 2100 \text { m., } \\
\text { 04.06.2019 }\end{array}$ & B. Çitak-348 \\
\hline \multirow[t]{2}{*}{ I. carnosa Willd. (I2) } & B5 Nevşehir: Ortahisar, 1300 m., 17.05.2015 & B. Çıtak-167-a (**) \\
\hline & Adana: Pozant1, Horozköy, 1000 m., 22.05.2018 & B. Çıtak-332 \\
\hline I. odorata L.(I3) & C6 Kahramanmaraş: Pazarcık, 800 m. 23.04.2018 & B. Çıtak-334 (**) \\
\hline \multirow[t]{2}{*}{ I. simplex DC. (I4) } & B5 Nevşehir, Akdağ, 1300 m., 29.05.2016 & B.Çıtak-180 (**) \\
\hline & Adana: Pozant1, $1000 \mathrm{~m}$. & B.Çıttak-333 \\
\hline I. carica Bornm. (I5) & C2 Muğla: Marmaris, 500 m., 25.05.2019 & B. Çıtak-345 (**) \\
\hline \multirow[t]{2}{*}{$\begin{array}{l}\text { I. halophila Vural \& H. } \\
\text { Duman*(I6) }\end{array}$} & $\begin{array}{l}\text { C4 Aksaray: Eskil, The Salt Lake, 920-950 m., } \\
\text { 19.05.2018 }\end{array}$ & B.Çıtak-335-a (**) \\
\hline & C4 Konya: Tersakan Lake, 900 m., 10.06.2019 & B. Çitak-351 \\
\hline $\begin{array}{l}\text { I. saxatilis } \mathrm{L} \text {. subsp. } \\
\text { saxatilis }(\mathrm{I} 7)\end{array}$ & B1 Balıkesir: Edremit, Kaz Dağı, 1600 m., 25.05.2018 & B.Çıtak-336 (**) \\
\hline $\begin{array}{l}\text { I. saxatilis subsp. } \\
\text { magnesiana Oskay* (I8) }\end{array}$ & B1 Manisa: Soma, 1000 m., 26.05.2018 & B.Çıtak-337 (**) \\
\hline
\end{tabular}

*Endemic taxa, (**) the photographing species.

Anatomical surveys

The paraffin method was used to prepare the permanent anatomical slides (Johansen, 1940). For each taxon, five plant samples were used and the experiments were done at least three times. The vegetative parts of the species were cut into small pieces. Next, they were treated through an increasing alcohol series to remove the water from the tissues. As the next step, a portion of paraffin was added to small glass flasks. The paraffin blocks were made and $12-16-\mu$ m-thick transverse sections were cut using a Thermo Scientific microtome with disposable blades. Under a light microscope (Leica DM 1000), the best sections were chosen and photographed at magnifications of 10x, 20x, and 40x. The measurements, which were made with the Kameram 21 software programme, were based on at least 30 or more cells per specimen. The mean values of the measurements of all of the investigated taxa were given. The root, stem, leaf, mature fruit and seed were used for anatomical studies.

\section{Numerical analysis}

For the numerical analysis, the qualitative and quantitative characters were scored. A total of 11 anatomical characters were used to evaluate the taxonomical similarities of the Iberis species (Table 2). A data matrix was set using the recorded qualitative and quantitative characters. Based on the anatomical characters, the coefficients of correlation among the eight species were determined and these species were grouped using the clustering analysis method (unweighted pair 
group method with arithmetic mean, UPGMA, dissimilarity, standardised variables). The clustering analysis was based on Gower's (1971) general coefficient similarity (Sneath and Sokal, 1973), which was used directly with a mixture of character types (binary, qualitative, and quantitative. Untransformed, centred, and unstandardized data were used to create a covariance matrix. In addition, principal component analysis (PCA) was used to ordinate the variables and identify the valuable all the selected anatomical characters used in taxonomy (Table 2). MVSP 3.22 software was used for all of the computations.

Table 2. Anatomical characteristics of Turkish Iberis species used for the numerical analysis.

\begin{tabular}{lll}
\hline Vegetative organ & Acronyms & Definition of anatomical characteristics \\
\hline Root & A1 & Root structure type \\
& A2 & Vessel diameter \\
& A3 & Number of vessels \\
Stem & A4 & Diameter of pith cells \\
& A5 & Aerenchyma \\
Leaf & A6 & Mesophyll thickness \\
& A7 & Length of palisade cells \\
& A8 & Width of palisade cells \\
& A9 & Row of palisade tissue \\
& A10 & Width of spongy parenchyma \\
& A11 & Leaf cross-section shape (triangular: 0, linear: 1) \\
\hline
\end{tabular}

\section{Results and Discussion}

The general anatomical descriptions of the root, stem, leaves, fruits, and seeds of the eight taxa were prepared (Table 3). The selected anatomical images, which best represented the examined taxa, are shown in Figs. 1-8. All scores related to the anatomical characters are given in Table 3.

Table 3. Anatomical data of Turkish Iberis species used for the numerical analysis.

\begin{tabular}{lcccccccc}
\hline Species/Characters & I1 & I2 & I3 & I4 & I5 & I6 & I7 & I8 \\
\hline A1 $(\mu \mathrm{m})$ & 652 & 407.32 & 459.58 & 625.66 & 304.43 & 1063.06 & 242.6 & 279.44 \\
A2 $(\mu \mathrm{m})$ & 112.6 & 64.6 & 73.81 & 86.83 & 74.5 & 55.7 & 26.33 & 37.16 \\
A3 $(\mu \mathrm{m})$ & 62.83 & 21.26 & 30.59 & 26.83 & 24.53 & 30.33 & 18.5 & 18.2 \\
A4 & 0 & 0 & 0 & 1 & 0 & 1 & 0 & 0 \\
A5 $(\mu \mathrm{m})$ & 42.66 & 30.84 & 44.28 & 41.73 & 23.96 & 29.26 & 21.66 & 38.24 \\
A6 $(\mu \mathrm{m})$ & 361.9 & 821 & 996 & 34.03 & 53.96 & 623.3 & 335.6 & 33.1 \\
A7 & 0 & 0 & 0 & 0 & 0 & 1 & 0 & 0 \\
A8 & 0 & 0 & 0 & 0 & 0 & 1 & 1 & 1 \\
A9 $(\mu \mathrm{m})$ & 77.3 & 50.12 & 36.72 & 45.8 & 33.13 & 48 & 31.86 & 32.24 \\
A10 & 0 & 0 & 0 & 1 & 0 & 1 & 1 & 1 \\
A11 & 0 & 0 & 0 & 1 & 0 & 1 & 1 & 1 \\
\hline
\end{tabular}




\section{Root anatomy}

The cross-sections of the root had different layers as protective tissue. I. saxatilis subsp. saxatilis, I. saxatilis subsp. magnesiana, I. sempervirens, I. halophila, and I. carnosa had a peridermis, whereas I. carnosa, I. odorata, and I. carica had an epidermis (Figs 1-2). The cortex parenchyma was on a small area of the roots in the studied species. Only I. halophila had large cavities (aerenchymatic area) in the cortex cells. The phloem and xylem were well-developed. The pith region was fully filled with xylem elements. The vessels were quite reduced in I. halophila.
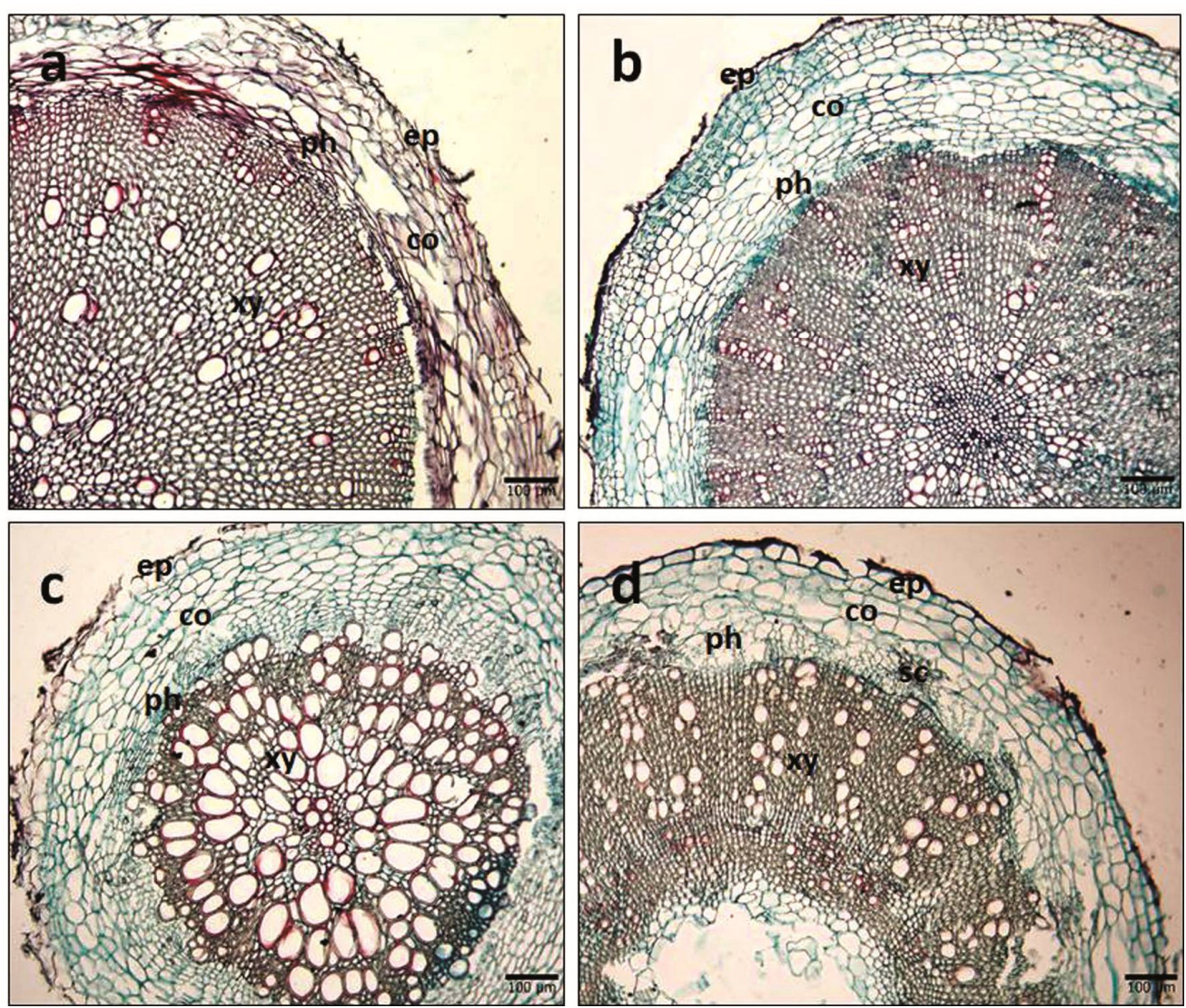

Fig. 1. Root anatomy of annual or biennial Turkish Iberis species: a. I. carica, b. I. odorata, c. I. carnosa, d. I. simplex. ep: epidermis, co: cortex parenchyma, ph: phloem, xy: xylem.

\section{Stem anatomy}

The transverse sections of the stem had an epidermis, cortex, and vascular bundles and a pith region towards the centre in all of the examined taxa. The epidermis was single-layered with ovalrectangular-shaped cells. The cortex parenchyma had chlorophyll pigments with oval-shaped cells. The ridges in the stem had collenchymatic cells. Phloem and xylem elements were found continuously in the stem. There were some sclerenchymatic cells over the phloem in the examined species, except in I. carnosa. The pith region was covered with oval-shaped parenchymatic cells (Figs 3-4). 


\section{Leaf anatomy}

The general view of the leaf cross-section showed the presence of an epidermis, mesophyll, and vascular bundles. The epidermis was limited to the leaves from the abaxial and adaxial sides. The cylindrical-shaped palisade parenchyma cells contained abundant chlorophyll pigments and they were arranged in 2 or 3 layers on both sides of the leaves. Only I. halophila had a greater number of palisade parenchyma cells in its leaves. Vascular bundles were found in a single line and the midvein vascular bundle was larger than the others. The aerenchymal area was developed in I. saxatilis subsp. saxatilis (Figs 5-6).
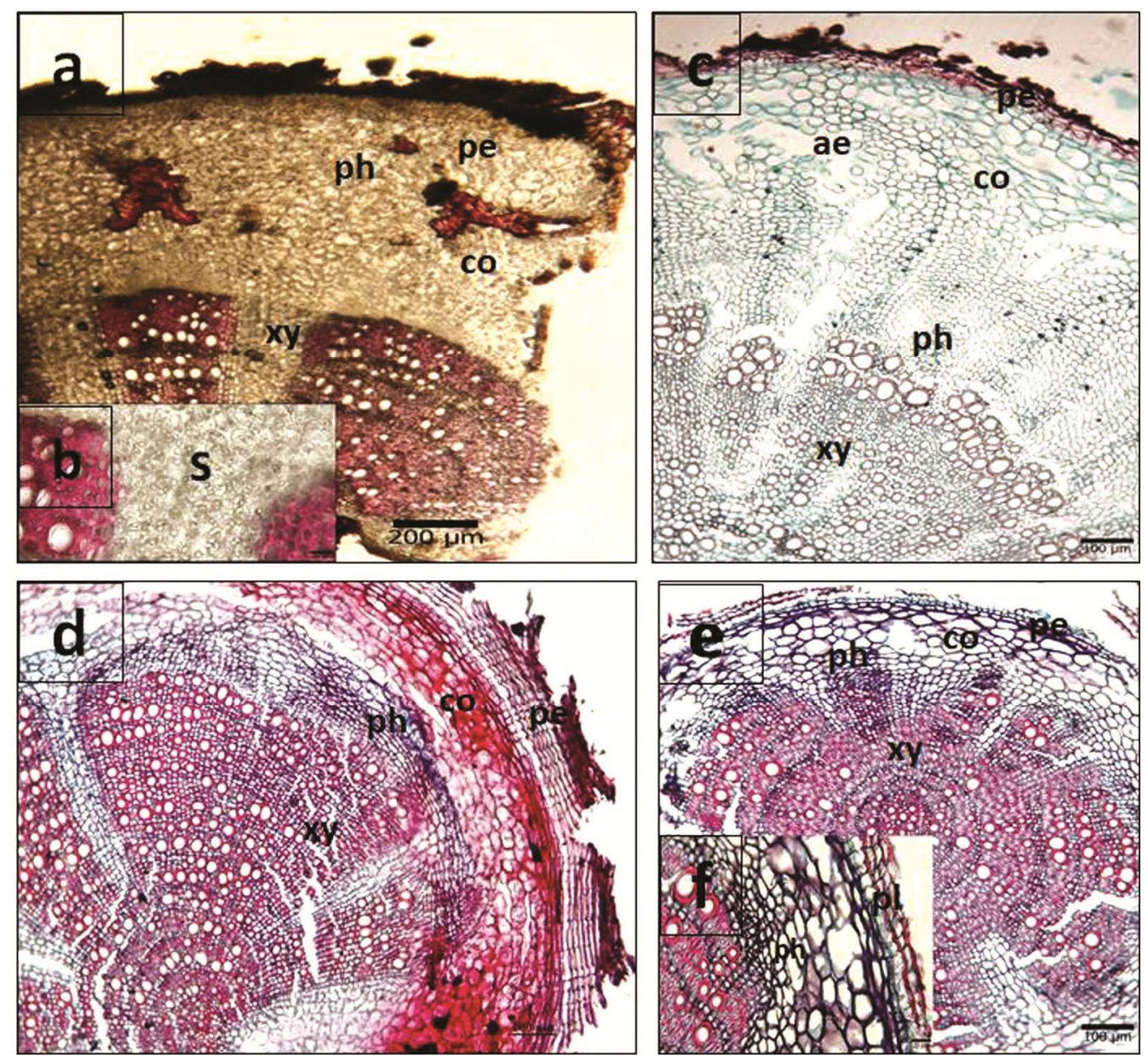

Fig. 2. Root anatomy of perennial Turkish Iberis species: a-b. I. sempervirens, c. I. halophila, d. I. saxatilis subsp. saxatilis, e-f. I. saxatilis subsp. magnesiana. ep: epidermis, co: cortex parenchyma, ph: phloem, xy: xylem, ae: aerenchyma, pl: phellem, s: starch.

\section{Fruit anatomy}

The findings of the anatomical studies of the fruit are shown in Table 3 and Fig. 7. The fruit wall was composed of 4 anatomical layers: the outer epidermis, parenchyma, sclerenchyma and endocarp. The wing contained abundant parenchyma cells. The mesocarp thickness varied in the studied species (Table 3). 

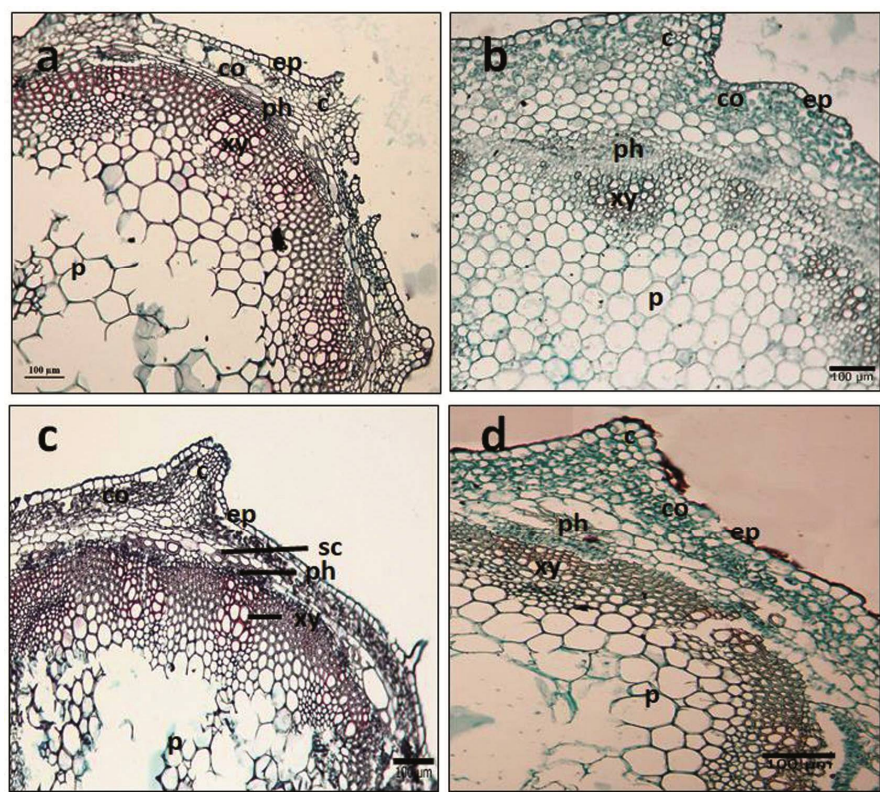

Fig. 3. Stem anatomy of annual and biennial Turkish Iberis species: a. I. carica, b. I. carnosa c. I. odorata, d. I. simplex. ep: epidermis, co: cortex parenchyma, ph: phloem, xy: xylem, c: collenchyma, p: parenchyma
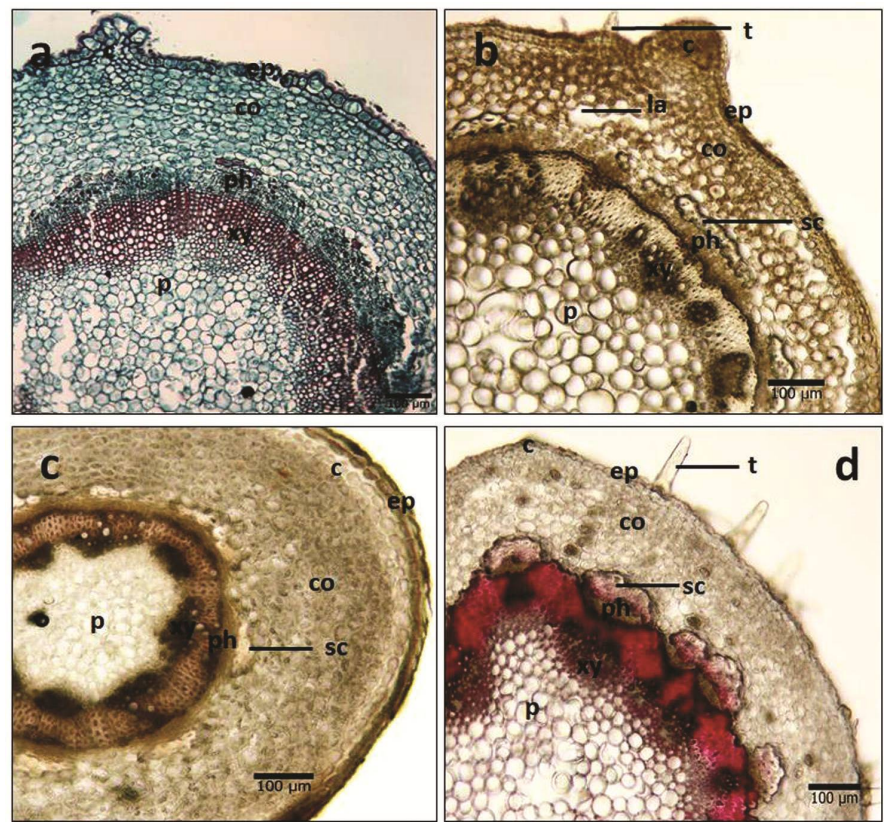

Fig. 4. Stem anatomy of perennial Turkish Iberis species: a. I. sempervirens, b. I. halophila, c. I. saxatilis subsp. saxatilis, d. I. saxatilis subsp. magnesiana. ep: epidermis, co: cortex parenchyma, ph: phloem, xy: xylem, c: collenchyma, p: parenchyma, t: trichome, sc: sclerenchyma, la: lacunae. 

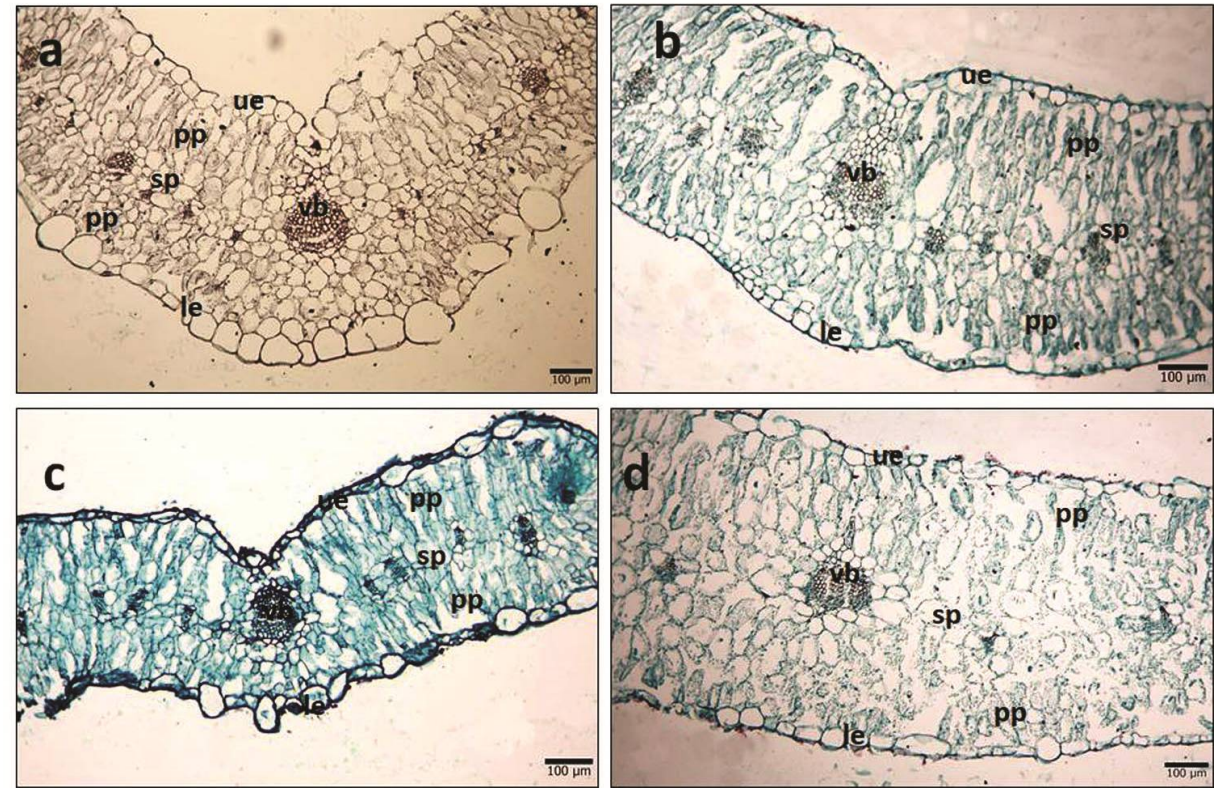

Fig. 5. The leaf anatomy of annual and biennial Turkish Iberis species: a. I. carica, b. I. carnosa, c. I. odorata, d. I. simplex. ue: epper epidermis, pp: palisade parenchyma, sp: spongy parenchyma, le: lower epidermis, vb: vascular bundle.
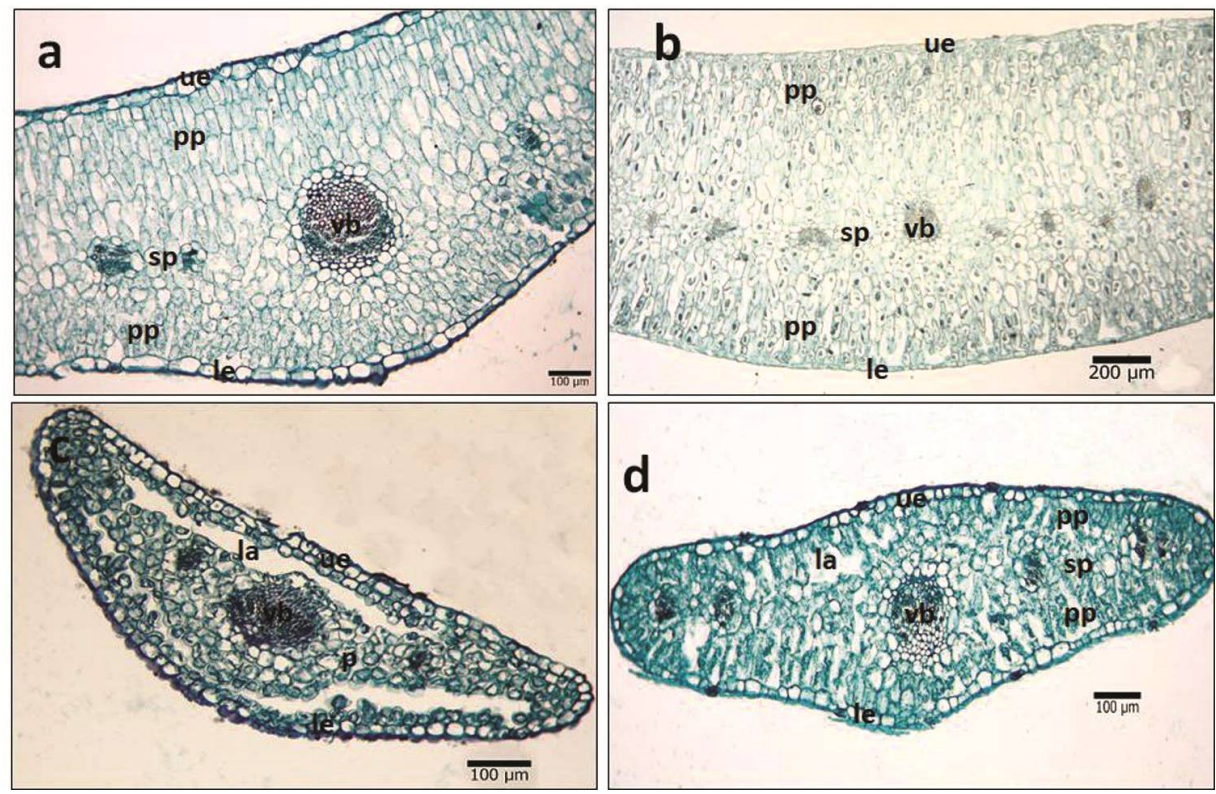

Fig. 6. The leaf anatomy of perennial Turkish Iberis species: a. I. sempervirens, b. I. halophila, c. I. saxatilis subsp. saxatilis, d. I. saxatilis subsp. magnesiana. ue: epper epidermis, pp: palisade parenchyma, sp: spongy parenchyma, le: lower epidermis, vb: vascular bundle, la: lacunae, p: parenchyma. 

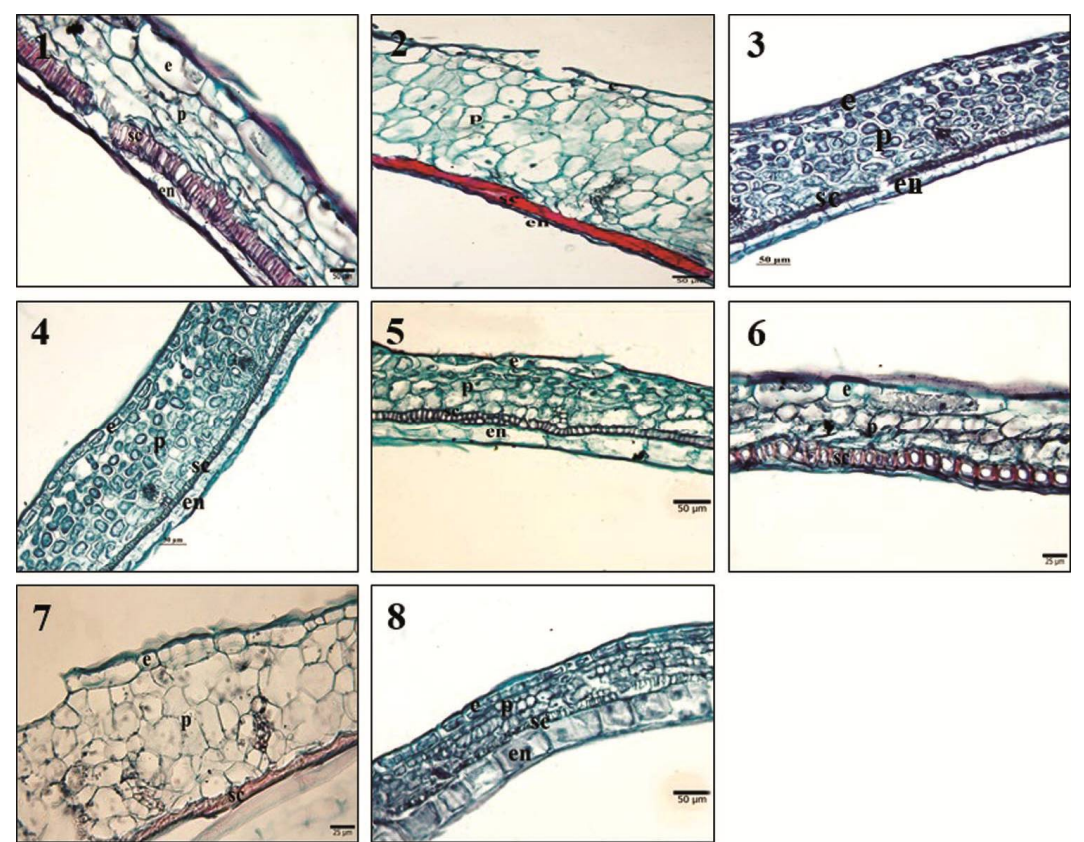

Fig. 7. The fruit wall anatomy of Turkish Iberis species: a. I. sempervirens, b. I. halophila, c. I. saxatilis subsp. saxatilis, d. I. saxatilis subsp. magnesiana. e: the outer epidermis, p: parenchyma; en: endocarp, sc: sclerenchyma.
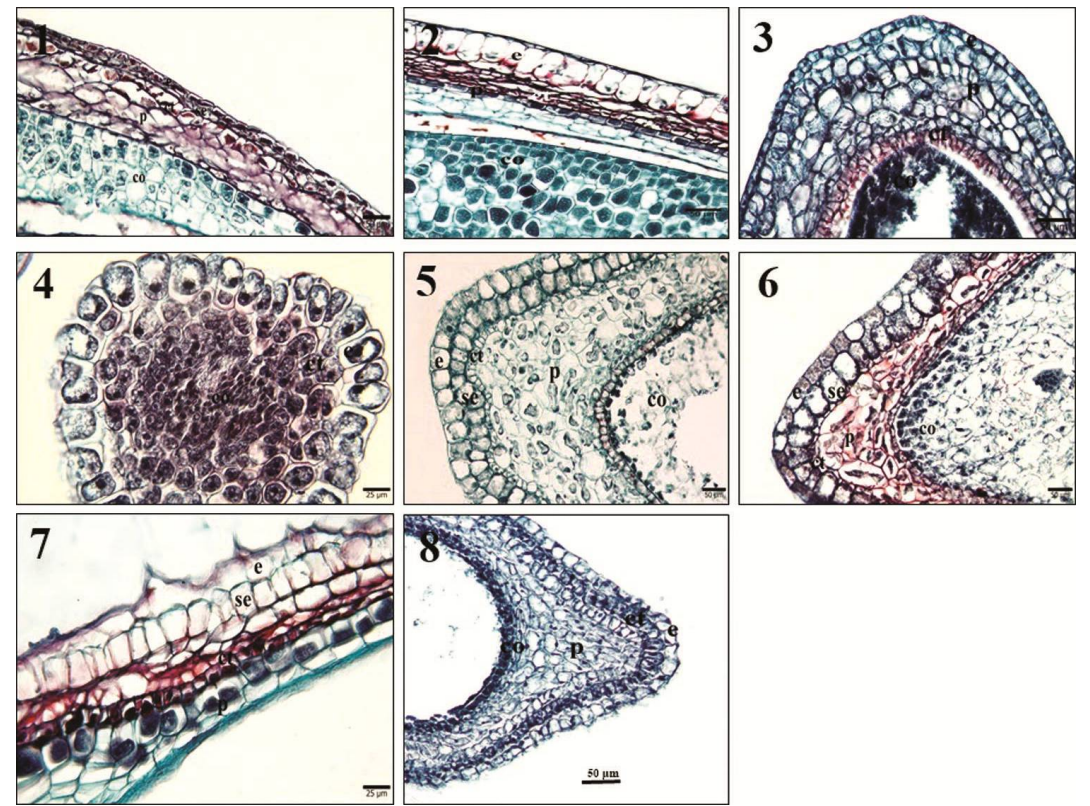

Fig. 8. The seed wall anatomy of Turkish Iberis species: a. I. sempervirens, b. I. halophila, c. I. saxatilis subsp. saxatilis, d. I. saxatilis subsp. magnesiana. e: the outer epidermis, se:subepidermis, p: parenchyma; ct: compressed tissue, co: cotyledon. 


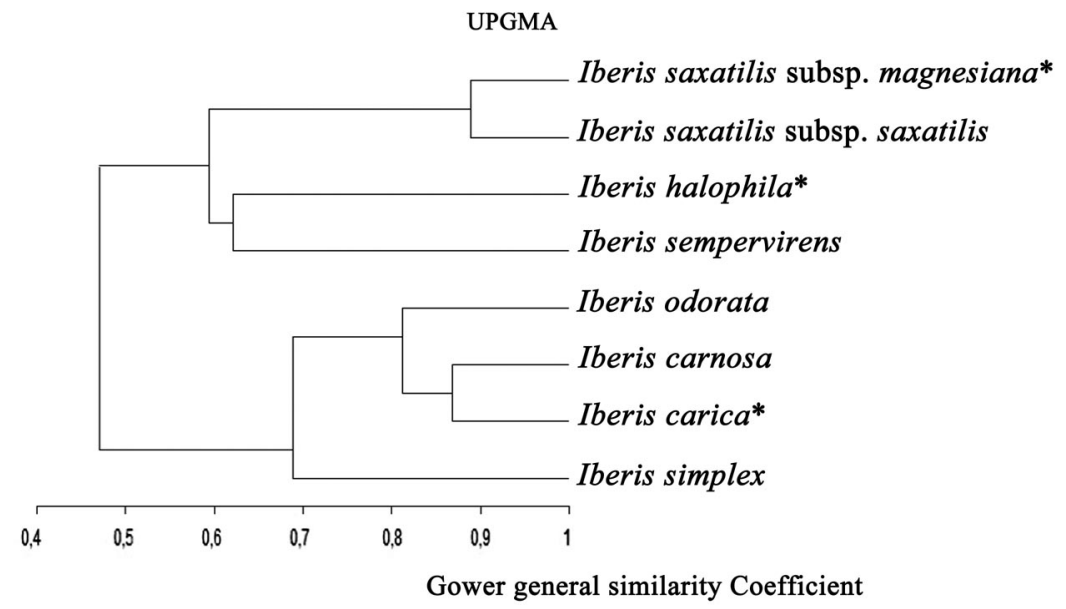

Fig. 9. Dendrogram based on anatomical traits showing the similarity and distance between Iberis species. Asterisks indicate endemic taxa.

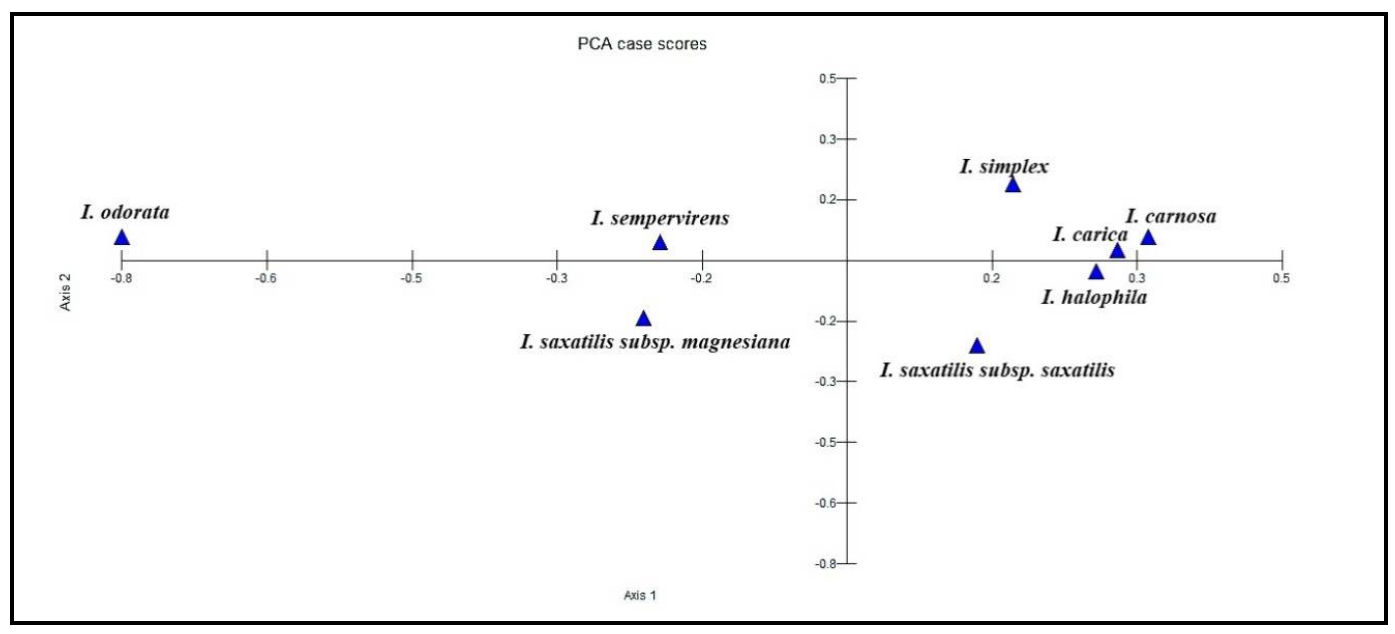

Fig. 10. Principal component analysis of examined Iberis species.

\section{Seed anatomy}

The findings of the anatomical investigations of the seeds are shown in Table 3 and Fig. 8. The seeds of the investigated taxa were composed of epidermis, subepidermis, compact tissue, parenchyma, and endosperm layers. The epidermis and subepidermis cells were oval or rectangular shaped in the examined species. The thickness of the testa was the thickest in $I$. carnosa and the thinnest in I. sempervirens (Table 3).

Numerical analysis of the anatomical character states

The dendrogram derived from the cluster analysis using the UPGMA based on the 11 anatomical variables of the eight Iberis species is presented in Fig. 9. This dendrogram reflected the similarities among the examined species. The dendrogram revealed two main groups: Group A (with $60 \%$ similarity) comprised four perennials of Turkish Iberis: I. saxatilis subsp. saxatilis, I. saxatilis subsp. magnesiana, I. sempervirens, and I. halophila. Group B (with 68\% similarity) 
comprised the remaining four taxa of the annuals and biennials of Turkish Iberis. Group A consisted of two main clusters, which were described further as Clusters $A_{1}$ and $A_{2}$. Cluster $A_{1}$ included subspecies of I. saxatilis, I. saxatilis subsp. saxatilis, and I. saxatilis subsp. magnesiana (with $88 \%$ similarity). Cluster $\mathrm{A}_{2}$ included two species: I. halophila and I. sempervirens (with $62 \%$ similarity). Group B consisted of 2 main clusters: Clusters $B_{1}$ and $B_{2}$. Cluster $B_{1}$ included 2 subclusters: $\mathrm{C}_{1}$ and $\mathrm{C}_{2} . \mathrm{C}_{1}$ contained I. odorata (with $81 \%$ similarity). $\mathrm{C}_{2}$ included I. carnosa and I. carica (with $86 \%$ similarity). Cluster $\mathrm{B}_{2}$ included only I. simplex.

The anatomical characteristics of the examination and designation of the family Brassicaceae has been based on the study by Metcalfe and Chalk (1950). In the current study, the diagnostic anatomical traits were determined as mesophyll, via the vessel diameter in the root and the presence of aerenchyma tissue. The species of Iberis were herbaceous annual and biennial, and perennial. The genus Iberis was not sufficiently identified by Hedge (1965). Çitak (2019) wanted to trait the genus by its palynological data. Our results supported the discrimination of Turkish Iberis based on palynomorphological characteristics previously indicated by Çitak (2019).

A generally accepted theory by Fahn (1990) was that the anatomy of the root was unchangeable, and the taxonomic value of the roots was very limited in many plant genera. The root anatomy of Turkish Iberis studied here was congruent with the life form of the species. The annual and biennial Iberis species had a primary root structure and the perennial ones had a secondary root structure. As can be seen from Table 3, the vessel diameter was the largest in $I$. carnosa, while the smallest was in I. saxatilis subsp. saxatilis. The number of vessels was the most crowded in I. halophila because of the characteristics of this halophytic species, not mentioned previously in Çilden and Zare (2019). Çilden and Zare (2019) indicated that I. carica had a perennial habit and isolateral leaf anatomy. However in this study, we confirmed that I. carica has a distinct annual herb with primary root anatomy. Additionally, I. carica has equifacial mesophyll type different from Çilden and Zare (2019)'s study.

The stem shape was rounded, semi-rounded, rectangle, circular, or irregular in the family Brassicaceae (Atçeken et al., 2016; Qader, 2018). The stem shape in the investigated Iberis taxa was circular, in addition to ridges with collenchymatic tissue. Cortex parenchymatic cells covered the small area in the cross-sections of stem. However, they contained starch molecules as stored materials. This arrangement has been declared by some researchers previously (Selvi and Paksoy, 2013; Atçeken et al., 2016). Sclerenchymatic tissue was found in the studied Iberis taxa, except in I. carnosa; however, their dimensions and amount were different among the species (Figs 4-5). Aerenchyma has generally been reported in the stems of marsh plants (Salisbury and Ross, 1985; Drew et al., 2000) or halophytic plants (Akcin et al., 2015). Accordingly, in the present study, aerenchymatic tissue was observed only in I. halophila, which grows in salty habitats. Yentür (2003) had declared that the arrangement of vascular bundles within the stem can be useful information for comparative anatomical studies. Our investigation of the stem cross-sections showed that in most of the taxa characterised by vascular bundles arranged in a ring, only $I$. halophila also had small cortical bundles among the main large vascular bundles (Figs $4 \mathrm{e}-4 \mathrm{~h}$, Table 3).

In the family Brassicaceae, the leaf anatomy has been used to characterise tribes and some genera (Selvi and Paksoy 2013). Interestingly, I. saxatilis subsp. saxatilis, and I. saxatilis subsp. magnesiana had aerenchymatic tissue in the leaf. Possibly, the moist habitat of these 2 subspecies could result in the aerenchymatic areas in leaf. In the present study, a unifacial mesophyll was only observed in I. saxatilis subsp. saxatilis, which grow in moist areas, while equifacial leaves were observed in the other investigated taxa, which mainly grow in the dry habitats of the IranoTuranian phytogeographic region of Turkey. According to Yentür (2003), equifacial leaves were generally characteristic of xerophytic plants, which was in accordance with the observations made 
herein. Accordingly, the number and volume of palisade parenchyma were larger in I. halophila, which grows in the salty habitats of Salt Lake.

The fruit and seed anatomical properties contained essential information about the taxonomy of the family Brassicaceae (Mummenhoff et al., 2008; Mühlhausen et al., 2010; Lenser et al., 2016). Karaismailoğlu (2019) declared that the testa thickness could be showed a great variation for Aethionema genus. In present study, the fruit and seed wall thicknesses of Iberis genus has been found as a great potential to separate its species.

The UPGMA dendrogram generated from the anatomical traits of the vegetative parts discriminated the species of Iberis according to their life forms. The positions of the Iberis species and their similarities reflected in the clusters were found to be agreeable with the previous large scale classification of the genus. Iberis saxatilis subsp. saxatilis and I. saxatilis subsp. magnesiana, which are local and/or very distinct endemic species, were in the same clade. The two subspecies could be easily separated from each other by the presence-absence of stem indumentum. In I. saxatilis subsp. magnesiana, the stem was retrorsely setulose, while the stem of I. saxatilis subsp. saxatilis was glabrous. Iberis sempervirens is a semi-shrub plant that has no close relative and I. halopila, which is a dwarf, perennial species, lives in salty habitats found in the same subclade, because of their similar anatomical characteristics. The other 4 annual or biennial Turkish Iberis species were positioned in the same clade. This position of the species was congruent with the Hedge (1965) classification system in Flora of Turkey.

PCA ordination and similarity matrix in accordance with anatomical traits of vegetative parts are shown in Fig. 10, in which I. carica and I. halophila are placed as the closest taxa, whereas $I$. odorata and I. carnosa as the most distant taxa. Additionally, the cumulative variance value of principal components achieved $81.8 \%$.

In conclusion, vessels in the roots and stems, mesophyll type, aerenchymatic tissue, mesocarp and testa thickness are the most valuable variables for distinguishing Iberis species. In further investigations we propose that the systematic problems of Iberis taxa should maybe solved by providing morphological and more molecular studies.

\section{References}

Akçin, T.A., Akçin, A. and Yalçın, E. 2015. Anatomical adaptations to salinity in Spergularia marina (Caryophyllaceae) from Turkey. Proc. Natl. Acad. Sci. India B. 85:625-634.

Al-Shehbaz, I.A. 1984.The tribes of Cruciferae (Brassicaceae) in the southeastern United States. J. Arnold Arbor. 65:343-373.

Al-Shehbaz, I.A.,Beilstein M.A. and Kellogg, E.A. 2006. Systematics and phylogeny of the Brassicaceae (Cruciferae): An overview. Plant Syst Evol. 259:89-120.

Al-Shehbaz, I.A. 2012. A generic and tribal synopsis of the Brassicaceae (Cruciferae). Taxon 61:931-954.

Atçeken, M.M., Dural, H. and Citak, B.Y. 2016. The morphological, anatomical and palynological investigations on some taxa of Genus Aethionema at Waiton (Brassicaceae). Biodicon 9:55-68.

Busch, A. and Zachgo, A. 2007. Control of corolla monosymmetry in the Brassicaceae Iberis amara. Proc. Natl. Acad. Sci. USA 104:16714-16719.

Citak, B.Y. 2019. A palynological survey of the genus Iberis (Brassicaceae), known as candytufts, in Turkey. Phytotaxa 397:213-224.

Çilden, E. and Zare, G. 2019. Comparative anatomical survey on the species of Iberis L. (Brassicaceae) from Turkey. Hacettepe J. Biol. \& Chem. 47: 389-401.

Drew, M.C., He, C.J. and Morgan, P.W. 2000. Programmed cell death and aerenchyma formation in roots. Trends Plant Sci. 5:123-127.

Fahn, A. 1990. Plant Anatomy. 4th Edition: Pergamon Press, Oxford. 
Franzke, A., Lysak, M.A., Al-Shehbaz, I.A., Koch, M.A. and Mummenhoff, K. 2011. Cabbage family affairs: the evolutionary history of Brassicaceae. Trends Plant Sci. 16:108-116.

Gower, J.C. 1971. A general coefficient of similarity and some of its properties. Biometrics 27:857-874.

Hedge, I.C. 1965. Iberis L. In: Davis Ph (Ed.), Flora of turkey and the east Aegean Islands. Edinburgh University Press, Edinburgh. pp. 12-309.

Huang, C.H., Sun, R.R., Hu, Y., Zeng, L., Zhang, N., Cai, L., Zhang, Q., Koch, M.A., Al-Shehbaz, I., Edger, P.P., Pires, J.C., Tan, D.Y., Zhong, Y. and Ma, H. 2016. Resolution of brassicaceae phylogeny using nuclear genes uncovers nested radiations and supports convergent morphological evolution. Mol. Biol. Evol. 33: 394-412.

Johansen, D.A. 1940. Plant Microtechique. Mcgraw-Hill Book Company, London.

Karaismailoğlu, M. 2019. Comparative morphology and anatomy of seeds of some Aethionema W.T. Aiton (Brassicaceae) taxa from Turkey. Bangladesh J. Plant Taxon. 26(1): 1-12.

Kiefer, M., Schmickl, R., German, D.A., Mandáková, T., Lysak, M.A., Al-Shehbaz, I.A., Franzke, A., Mummenhoff, K., Stamatakis, A. and Koch, M.A. 2014. Brassibase: Introduction To a novel knowledge database on brassicaceae evolution. Plant Cell Physiol. 55: e3.

Koch, M.A, Kiefer, M., German, D., Al-Shehbaz, I.A., Franzke, A., Mummenhoff, K. and Schmicki, R. 2012. Brassibase: Tools and biological resources to study characters and traits in the BrassicaceaeVersion 1.1. Taxon 61:1001-1009.

Lenser, T., Graeber, K., Çevik, Ö.S., Adıgüzel, N., Dönmez, A.A., Grosche, C., Kettermann, M., MaylandQuellhorst, S., Mérai, Z., Mohammadin, S., Nguyen, T., Rümpler, F., Schulze, C., Sperber, K., Steinbrecher, T., Wiegand, N., Strnad, M., Scheid, O.M., Rensing, S.A., Schranz, M.E., Theißen, G., Mummenhoff, K., Leubner-Metzger, G. 2016. Developmental control and plasticity of fruit and seed dimorphism in Aethionema arabicum. Plant Physiology 172: 1697-1707.

Metcalfe, C.R.and Chalk, L. 1950. Anatomy of the Dicotyledons (Leaves, stem and wood in relation to taxonomy with notes on economic uses). Oxford University Press, Clarendon Press, London.

Mutlu, B. 2012. Iberis L. In: Güner, A., Arslan, S., Ekim, T., Vural, M., Babaç, M.T. (Eds.), Türkiye Bitkileri Listesi (Damarlı Bitkiler). Nezahat Gökyiğit Botanik Bahçesi ve Flora Araştırmaları Derneği Yayın1, İstanbul. pp. 281-282.

Mummenhoff, K., Polster, A., Mühlhausen, A., Theißen, G. 2008. Lepidium as a model system for studying the evolution of fruit development in Brassicaceae. J Exp Bot. 60: 1503-1513.

Mühlhausen, A., Polster, A., Theissen, G., Mummenhoff, K. 2010. Evolution of fruit dehiscence in Brassicaceae: examples from Aethionema and Lepidium. VI International Symposium on Brassicas and Xviii Crucifer Genetics Workshop. 867: 207-219.

Oskay, D. 2017. A new subspecies of Iberis saxatilis (Brassicaceae) from Turkey. Phytotaxa 306:153-158.

Prabhakar, K. and Vijayaraghavan, M.R.1983. Embryo Sac Wall in Iberis amara and Alyssum maritimum. Phyton (Austria) 23: 31-38.

Qader, K.O. 2018. Taxonomic significance of anatomical characters in some species of Brassicaceae family in Iraq. J. Thi-Qar Science 6:77-83.

Salisbury, F.B. and Ross, C.W. 1985. Plant Physiology. 3rd Edition, Wadsworth Publishing Co., Belmont.

Selvi, S. and Paksoy, M.Y. 2013. Comparative anatomy of stem and leaf of Ricotia L. growing in Turkey. Bangladesh J. Bot. 42:123-130.

Sneath, P.H.and R.R. Sokal. 1973. Numerical Taxonomy, The principles and practice of numerical classification. 1st Ed. San Francisco, Ca, USA, Wh Freeman.

Yentür, S. 2003. Bitki Anatomisi. İstanbul Üniversitesi Fen Fakültesi Yayınları, İstanbul (In Turkish).

(Manuscript received on 12 June, 2020; revised on 5 November, 2020) 